Old Dominion University

ODU Digital Commons

OEAS Faculty Publications

Ocean, Earth \& Atmospheric Sciences

$11-2000$

\title{
Modifications of the C37 Alkenone and Alkenoate Composition in the Water Column and Sediment: Possible Implications for Sea Surface Temperature Estimates in Paleoceanography
}

Joan O. Grimalt

Jürgen Rullkötter

Marie-Alexandrine Sicre

Roger Summons

John Farrington

See next page for additional authors

Follow this and additional works at: https://digitalcommons.odu.edu/oeas_fac_pubs

Part of the Biogeochemistry Commons, Geophysics and Seismology Commons, Marine Biology Commons, Oceanography Commons, and the Sedimentology Commons

\section{Repository Citation}

Grimalt, Joan O.; Rullkötter, Jürgen; Sicre, Marie-Alexandrine; Summons, Roger; Farrington, John; Harvey, H. Rodger; Goñi, Miguel; and Sawada, Ken, "Modifications of the C37 Alkenone and Alkenoate Composition in the Water Column and Sediment: Possible Implications for Sea Surface Temperature Estimates in Paleoceanography" (2000). OEAS Faculty Publications. 158.

https://digitalcommons.odu.edu/oeas_fac_pubs/158

\section{Original Publication Citation}

Grimalt, J.O., Rullkötter, J., Sicre, M.A., Summons, R., Farrington, J., Harvey, H.R., . . Sawada, K. (2000). Modifications of the C37 alkenone and alkenoate composition in the water column and sediment: Possible implications for sea surface temperature estimates in paleoceanography. Geochemistry, Geophysics, Geosystems, 1(11), 1-20. doi: 10.1029/2000GC000053 
Authors

Joan O. Grimalt, Jürgen Rullkötter, Marie-Alexandrine Sicre, Roger Summons, John Farrington, H. Rodger Harvey, Miguel Goñi, and Ken Sawada 


\section{Modifications of the $\mathrm{C}_{37}$ alkenone and alkenoate composition in the water column and sediment: Possible implications for sea surface temperature estimates in paleoceanography}

\section{Joan O. Grimalt}

Department of Environmental Chemistry, Institute of Chemical and Environmental Research (CSIC), Jordi Girona, 18 08034-Barcelona, Catalonia, Spain (jgoqam@cid.csic.es)

\section{Jürgen Rullkötter}

Institut fuer Chemie und Biologie des Meeres, Universitaet Oldenburg, Postfach 2503, D-26111 Oldenburg, Germany (J.Rullkoetter@icbm.de)

\section{Marie-Alexandrine Sicre}

Laboratoire des Sciences du Climat et de l'Environment, Domaine, CNRS, Avénue de la Terrasse, 91191 Gif sur Yvette Cedex, France (Marie-Alexandrine.Sicre@1sce.cnrs-gif.fr)

\section{Roger Summons}

Australian Geological Survey Organisation, GPO Box 378, Canberra ACT 2601, Australia (rsummons@whoi.edu)

\section{John Farrington}

Fye Laboratory, Department of Marine Chemistry and Geochemistry, Woods Hole Oceanographic Institution, 360 Woods Hole Road, Woods Hole, Massachusetts 02543-1543 (jfarrington@whoi.edu)

\section{H. Rodger Harvey}

Chesapeake Biological Laboratory, University of Maryland Center for Environmental Science, P.O. Box 38, Solomons, Maryland 20688 (harvey@cbl.umces.edu)

\section{Miguel Goñi}

Department of Geological Sciences, Marine Science Program, Earth and Water Sciences Building, 302, University of South Carolina, Columbia, South Carolina 29208 (goni@geol.sc.edu)

\section{Ken Sawada}

Department of Chemistry, University of Tsukuba, Tsukuba, Ibaraki 305-8571, Japan

(sawadak@staff.chem.tsukuba.ac.jp)

[1] Abstract: The literature pertaining to $\mathrm{C}_{37}$ alkenone and $\mathrm{C}_{37}$ and $\mathrm{C}_{38}$ alkenoate production and diagenesis has been reviewed and evaluated for issues that might jeopardize their usefulness in paleotemperature estimation. We also examined the use of the $\mathrm{C}_{37}$ alkenones as paleoproductivity indicators, the stability of their $\delta^{13} \mathrm{C}$ isotopic compositions, and their incorporation into the nonsolvent extractable organic matter fraction. Biological transformation of organic matter by bacteria and zooplankton does not appear to cause significant changes to the ratio of $\mathrm{C}_{37: 2}$ and $\mathrm{C}_{37: 3}$ alkenones, but there are major alterations in the relative composition of alkenoates. Studies of water column processes and postdepositional sedimentary changes indicate overall stability in the $\mathrm{C}_{37: 2} /\left(\mathrm{C}_{37: 2}+\mathrm{C}_{37: 3}\right)$ ratio, 
leading to effective preservation of the paleotemperature signal. This is not the case for alkenoates, and there also appear to be some doubts about the dependence between sea surface temperature and the sedimentary abundance of the $\mathrm{C}_{37: 4}$ alkenone. $\mathrm{C}_{37}$ alkenones may provide useful qualitative estimates of marine paleoproductivity. Although these compounds are apparently only derived from Haptophycea, changes in their quantitative composition might reflect changes in nutrient availability that on sedimentary timescales should also be generally significant of other algal species. One caveat is that in highly productive upwelling systems, productivity may be expressed mostly in diatom growth and thus not measurable by the $\mathrm{C}_{37}$ alkenones. No changes in $\delta^{13} \mathrm{C}_{37}$ alkenone composition are observed upon zooplankton ingestion. Although this is expected from a theoretical perspective, further studies are encouraged in order to fully assess the stability of the isotopic signal during $\mathrm{C}_{37}$ alkenone diagenesis. Finally, alkenones bound in the nonextractable fraction of sedimentary organics have not been adequately studied and further work is required to clarify any possible correspondence with a temperature signal.

Keywords: $\mathrm{C}_{37}$ alkenones; sea surface temperatures; degradation; paleoproductivity; bound alkenones; alkenoates.

Index terms: Organic geochemistry; oceans; paleoclimatology; paleoceanography.

Received February 22, 2000; Revised September 11, 2000; Accepted October 10, 2000;

Published November 10, 2000.

Grimalt, J. O., J. Rullkötter, M.-A. Sicre, R. Summons, J. Farrington, H. R. Harvey, M. Goñi, and K. Sawada, 2000. Modifications of the $\mathrm{C}_{37}$ alkenone and alkenoate composition in the water column and sediment: Possible implications for sea surface temperature estimates in paleoceanography, Geochem. Geophys. Geosyst., vol. 1, Paper number 2000GC000053 [9792 words, 1 figures, 3 tables]. Published November 10, 2000.

Theme: Alkenones Guest Editors: John Hayes

\section{Introduction}

[2] The temperature estimates using the $\mathrm{C}_{37}$ alkenones are based on the compilation of two indices that are linearly correlated with sea surface temperature (SST) [Brassell et al., 1986a]:

$$
\begin{gathered}
\mathrm{U}_{37}^{\mathrm{K}}=\left(\mathrm{C}_{37: 2}-\mathrm{C}_{37: 4}\right) /\left(\mathrm{C}_{37: 2}+\mathrm{C}_{37: 3}+\mathrm{C}_{37: 4}\right), \\
\mathrm{U}_{37}^{\mathrm{K}^{\prime}}=\mathrm{C}_{37: 2} /\left(\mathrm{C}_{37: 2}+\mathrm{C}_{37: 3}\right),
\end{gathered}
$$

where $\mathrm{C}_{37: \mathrm{X}}$ denotes the concentration of the alkenone with $\mathrm{x}$ carbon-carbon double bonds.

[3] Examination of laboratory cultures of the precursor organisms [Prahl and Wakeham, 1987; Prahl et al., 1988], water column parti- culate organic matter [Prahl and Wakeham, 1987; Sikes and Volkman, 1993; Sikes et al., 1997; Ternois et al., 1997], and core tops [Sikes et al., 1991; Pelejero and Grimalt, 1997; Rosell-Melé et al., 1995; Sonzogni et al., 1997; Müller et al., 1998] have confirmed the linear dependence between $\mathrm{U}_{37}^{\mathrm{K}} / \mathrm{U}_{37}^{\mathrm{K}^{\prime}}$ and SST, over a wide temperature range.

[4] According to the ratios defined above, SST estimation will be biased if selective transformation of $\mathrm{C}_{37: 2}, \mathrm{C}_{37: 3}$, or $\mathrm{C}_{37: 4}$ alkenones occurs during transport through the water column or sediment storage. No bias will be produced if all $\mathrm{C}_{37}$ alkenones are degraded in the same proportion, even in processes of extensive alteration. 
[5] In principle, there is a general agreement that $\mathrm{C}_{37}-\mathrm{C}_{39}$ alkenones are among the most refractory lipids known. The causes of this resistance to degradation may be related to low-solubility, protective package within the algal cells and their unusual $\mathrm{Z}$ (trans) double bond configuration [Rechka and Maxwell, 1988] because many bacteria do not have enzymatic systems for the transformation of this type of double bonds [Brassell, 1983].

[6] The principal structural difference between the alkenones included in the $\mathrm{U}_{37}^{\mathrm{K}}$ indices relates to the degrees of unsaturation, i.e., $\mathrm{C}_{37: 2}, \mathrm{C}_{37: 3}$, and $\mathrm{C}_{37: 4}$. In general, the more degrees of unsaturation, the more easily a lipid is degraded. However, in these alkenones the low number of double bonds in relation to the chain length and the wide separation of these bonds in the carbon chain [Rechka and Maxwell, 1988] a priori suggest similar refractory properties of all compounds. Obviously, this has to be tested by field measurements and microbial degradation experiments.

[7] Another aspect needing further evaluation is the usefulness of the $\mathrm{C}_{37: 4}$ compounds for temperature measurement. In practice, most $\mathrm{C}_{37}$ alkenone-based paleotemperature studies use the $\mathrm{U}_{37}^{\mathrm{K}^{\prime}}$ index. This is due to the low amount of the $\mathrm{C}_{37: 4}$ alkenone in many sedimentary samples. However, attention should be paid to those cases in which the $\mathrm{C}_{37: 4}$ alkenone is abundant.

[8] The $\mathrm{C}_{36: \mathrm{x}}$ methyl and $\mathrm{C}_{38: 2}$ ethyl alkenoates have also been proposed for evaluation of SST [Conte et al., 1992]. Thus the influence of the degradation processes on these compounds requires evaluation.

[9] Given these considerations, the present report summarizes the available data on the transformation of $\mathrm{C}_{37}$ alkenones and $\mathrm{C}_{36: \mathrm{x}}$ and $\mathrm{C}_{38: 2}$ alkenoates during passage through the water column and after deposition in the sediments. The available information is interpreted in terms of the significance of these processes for paleotemperature estimation. Three main topics will be addressed: transformation by biota, changes in the water column, and postdepositional transformation. Other aspects such as the usefulness of the $\mathrm{C}_{37: 4}$ alkenone, nonsolvent extractable $\mathrm{C}_{37}$ alkenones, their use as paleoproductivity indicators, and the stability of their $\delta^{13} \mathrm{C}$ composition are also considered.

\section{Possible Bias Due to the Analytical Methods}

[10] Although the analytical problems associated with the use of $\mathrm{C}_{37}$ alkenones for paleotemperature estimation are not the focus of the present report, some attention has to be devoted to this topic as analytical errors are sometimes attributed to selective alkenone degradation.

[11] No alteration of $\mathrm{C}_{37}$ alkenone mixtures stored under current research storage conditions $\left(5^{\circ}-10^{\circ} \mathrm{C}\right.$ ambient temperature, darkness and adequate wrapping for maintenance of the sediments with their original seawater content) was detected in the study conducted by Brassell et al. [1986b]. Similar results were reported by Sikes et al. [1991] in a work of sediments from the Equatorial East Atlantic. In this latter work, no significant changes between samples stored frozen and at room temperature (even after 2 years) were observed.

[12] Sikes et al. [1991] also reported no changes in $\mathrm{C}_{37}$ alkenone composition after acidification for carbonate removal. They interpreted the results as indicating the persistence of the $\mathrm{C}_{37}$ alkenone signal despite of carbonate dissolution in the marine environment.

[13] During repeated gas chromatographic measurements, major deviations of $\mathrm{U}_{37}^{\mathrm{K}^{\prime}}$ determinations have been observed as consequence of 
capillary column adsorption effects [Villanueva and Grimalt, 1997]. These effects shift the $\mathrm{U}_{37}^{\mathrm{K}^{\prime}}$ indices toward higher values (warmer temperatures) due to stronger adsorption of the $\mathrm{C}_{37: 3}$ compound. The deviations are significant when the amount of $\mathrm{C}_{37}$ alkenones injected onto the capillary column is low. This instrumental limitation defines a threshold of minimal sample concentration below which $\mathrm{U}_{37}^{\mathrm{K}^{\prime}}$ determinations are not reliable [Villanueva and Grimalt, 1997].

[14] These adsorption effects may be significant in some studies reported in the literature. In the context of the present review, they are important for the interpretation of the results from one paper reporting postdepositional sedimentary alteration of $\mathrm{U}_{37}^{\mathrm{K}^{\prime}}$ index in turbidites [Hoefs et al., 1998]. The implications will be discussed in the section on sediment changes.

\section{Degradation Experiments With Biota}

[15] Published information is restricted to bacteria and zooplankton. As far as we are aware, specific studies involving protists, benthic grazers, or burrowing metazoans have not been undertaken.

[16] Microbial degradation experiments of $\mathrm{C}_{37: 3}$ and $\mathrm{C}_{37: 2}$ alkenone mixtures with $\mathrm{U}_{37}^{\mathrm{K}^{\prime}}=0.78$ and 0.6 under oxic, sulphate-reducing, and methanogenic conditions showed that these compounds are degraded at a lower rate than most other lipids [Teece et al., 1995, 1998]. The maximal percentages of consumption in these experiments were 83,43 , and $80 \%$, respectively. After this extent of degradation the differences in $\mathrm{U}_{37}^{\mathrm{K}^{\prime}}$ index were $+0.01,-0.013$, and -0.003 , respectively, involving less than $0.4^{\circ} \mathrm{C}$ bias in the worst case.

[17] For zooplankton, Volkman et al. [1980] reported feeding experiments of Emiliania hux- leyi to Calanus helgolandicus, showing that only a very small percentage of alkenones was assimilated or transformed by the copepod. In contrast, $\sim 70 \%$ of the fatty acids and sterols were consumed. Similar results were obtained in a subsequent study on the copepod Temora longicornis feeding on Isochrysis galbana in which it was found that $\mathrm{C}_{37}$ alkenones were absent from the grazer bodies but abundant in the fecal pellets [Grice et al., 1998]. The maximal $\mathrm{U}_{37}^{\mathrm{K}^{\prime}}$ difference between dietary algae and released pellets was 0.03 , equivalent to $0.9^{\circ} \mathrm{C}$. The same authors reported no significant changes in $\delta^{13} \mathrm{C}$ alkenone composition of these two materials.

\section{Postdepositional Sedimentary Changes}

[18] The transformation of organic matter, including lipids, after sedimentation strongly depends on the activity of microbiota and benthic organisms, at least during the first stages of diagenesis. To this end, the above reported degradation experiments with different types of bacteria [Teece et al., 1998] are very relevant. However, studies addressing the transformation of the $\mathrm{C}_{37}$ alkenones in real sedimentary environments are needed for a more complete understanding of the stability of the $\mathrm{U}_{37}^{\mathrm{K}^{\prime}}$ ratio.

[19] One significant outcome from these studies of sediment cores documents a significant decrease in alkenone concentration during early diagenesis, e.g., in the upper sedimentary column [Sun and Wakeham, 1994; Gong and Hollander, 1999; McCaffrey et al., 1990; Madureira et al., 1995]. This decrease is common for all sedimentary lipids. In fact, the alkenones are one of the lipid groups more resistant to diagenesis [Sun and Wakeham, 1994; Gong and Hollander, 1997, 1999]. Fatty acids, sterols, and alkanols are degraded at faster rates than the alkenones that exhibit a resistance similar to long-chain alkanes, alken- 
Table 1. Selected Data from Hoefs et al. [1998] Showing the Consistency of the Oxidized-Unoxidized Temperature Differences and Low $\mathrm{C}_{37: 3}$ Concentrations Close to Limit of Detection

\begin{tabular}{|c|c|c|c|c|c|c|}
\hline & $\begin{array}{c}\mathrm{C}_{37: 3} \\
\mu \mathrm{g} / \mathrm{g} \text { dry wt }\end{array}$ & $\begin{array}{c}C_{37: 2} \\
\mu \mathrm{g} / \mathrm{g} \text { dry wt }\end{array}$ & $\begin{array}{c}\mathrm{C}_{37} \\
\text { Alkenones, } \\
\mu \mathrm{g} / \mathrm{g} \text { dry wt }\end{array}$ & $\mathrm{U}_{37}^{\mathrm{K}^{\prime}}$ & $\begin{array}{l}\text { Temperature, } \\
{ }^{\circ} \mathrm{C}\end{array}$ & $\begin{array}{c}\text { Oxidized- } \\
\text { Unoxidized } \\
\text { Temperature } \\
\text { Difference, } \\
{ }^{\circ} \mathrm{C}\end{array}$ \\
\hline \multicolumn{7}{|c|}{ Free Lipids } \\
\hline \multicolumn{7}{|l|}{ Late Pliocene } \\
\hline Oxidized & 0.06 & 0.23 & 0.29 & 0.79 & 22.2 & 0.7 \\
\hline Nonoxidized & 3.06 & 10.3 & 13.4 & 0.77 & 21.5 & \\
\hline \multicolumn{7}{|l|}{ Early Pliocene } \\
\hline Oxidized & 0.02 & 0.26 & 0.28 & 0.93 & 26.2 & 1.9 \\
\hline Nonoxidized & 2.43 & 15.45 & 17.88 & 0.86 & 24.3 & \\
\hline \multicolumn{7}{|l|}{ Late Miocene } \\
\hline Oxidized & 0.01 & 0.12 & 0.13 & 0.92 & 26.0 & 1.4 \\
\hline Nonoxidized & 8.49 & 58.9 & 67.39 & 0.87 & 24.6 & \\
\hline \multicolumn{7}{|c|}{ Bound Lipids } \\
\hline Late Pliocene & & & & & & \\
\hline Oxidized & 0.20 & 0.86 & 1.06 & 0.81 & 22.7 & 0.4 \\
\hline Nonoxidized & 0.59 & 2.32 & 2.91 & 0.80 & 22.3 & \\
\hline \multicolumn{7}{|l|}{ Early Pliocene } \\
\hline Oxidized & n.d. & 0.06 & 0.06 & 1 & 28.3 & 2.5 \\
\hline Nonoxidized & 0.32 & 3.56 & 3.88 & 0.92 & 25.8 & \\
\hline \multicolumn{7}{|l|}{ Late Miocene } \\
\hline Oxidized & n.d. & 0.02 & 0.02 & 1 & 28.3 & 3.5 \\
\hline Nonoxidized & 0.39 & 2.90 & 3.29 & 0.88 & 24.8 & \\
\hline
\end{tabular}

diols, and alkanonols [Sun and Wakeham, 1994].

[20] Obviously, the degradation rates depend on the sedimentary conditions. The concentrations of $\mathrm{C}_{37}$ alkenones decrease faster in oxic [Madureira et al., 1995; Gong and Hollander, 1997, 1999] than in anoxic environments [Sun and Wakeham, 1994; Gong and Hollander, 1997, 1999]. Postdepositional oxidation episodes also involve strong decreases in $\mathrm{C}_{37}$ alkenone concentrations [Prahl et al., 1989a].

[21] However, the relevant point for paleoceanographic studies is whether the $\mathrm{U}_{37}^{\mathrm{K}^{\prime}}$ ratio is altered as a consequence of these diagenetic processes. McCaffrey et al. [1990] in core tops from the Peru margin reported no significant changes in $\mathrm{U}_{37}^{\mathrm{K}^{\prime}}$ (corresponding to a variation between $19.5^{\circ}$ and $20^{\circ} \mathrm{C}$ only) despite a decrease of total alkenone concentration of $30 \%$. Likewise, no modifications in $\mathrm{U}_{37}^{\mathrm{K}^{\prime}}$ were observed by Madureira et al. [1995] in the upper centimeters of oxic sediments (Biscay Abyssal Plain, North Atlantic) despite a significant decrease in $\mathrm{C}_{37}$ alkenone concentrations $(60 \%)$.

[22] In a study of Late Quaternary sediments from the Madeira Abyssal Plain, Prahl et al. [1989a] reported no changes in $\mathrm{C}_{37}$ alkenone composition and therefore no changes in $\mathrm{U}_{37}^{\mathrm{K}^{\prime}}$, despite of comprehensive postdepositional degradation of alkenones under contrasting (oxidized-unoxidized) redox conditions (Table 1 and 2).

[23] Hoefs et al. [1998] also analyzed the turbidites from the Madeira Abyssal Plain 
Table 2. Selected Data from Prahl et al. [1989] Showing the Lack of Temperature Differences Between Oxidized-Unoxidized Sediment Sections

\begin{tabular}{|c|c|c|c|c|c|c|}
\hline & $\begin{array}{c}\mathrm{C}_{37: 3}, \\
\mu \mathrm{g} / \mathrm{g} \text { dry wt }\end{array}$ & $\begin{array}{c}\mathrm{C}_{37: 2}, \\
\mu \mathrm{g} / \mathrm{g} \text { dry wt }\end{array}$ & $\begin{array}{c}\mathrm{C}_{37} \\
\text { Alkenones, } \\
\mu \mathrm{g} / \mathrm{g} \text { dry wt }\end{array}$ & $\mathrm{U}_{37}^{\mathrm{K}^{\prime}}$ & $\begin{array}{l}\text { Temperature, } \\
{ }^{\circ} \mathrm{C}\end{array}$ & $\begin{array}{l}\text { Oxidized- } \\
\text { Unoxidized } \\
\text { Temperature } \\
\text { Difference, } \\
{ }^{\circ} \mathrm{C}\end{array}$ \\
\hline \multicolumn{7}{|c|}{ Late Quaternary Core 86P5 } \\
\hline Oxidized & 0.26 & 0.68 & 0.94 & 0.72 & 19.9 & 0.6 \\
\hline Nonoxidized & 2.8 & 6.8 & 9.6 & 0.70 & 19.3 & \\
\hline \multicolumn{7}{|c|}{ Late Quaternary Core $86 \mathrm{P} 25$} \\
\hline Oxidized & 0.34 & 0.86 & 1.2 & 0.72 & 19.9 & 0.3 \\
\hline Nonoxidized & 2.5 & 6.2 & 8.7 & 0.71 & 19.6 & \\
\hline
\end{tabular}

(although in Pliocene and Miocene sections) and reported results different from those of Prahl et al. [1989a]. They noted that oxidation involved significant changes of the $\mathrm{U}_{37}^{\mathrm{K}^{\prime}}$ ratio in one of the sections. However, these latter measurements were made at extremely low alkenone concentrations (Table 1 and 2).

[24] A summary of the $\mathrm{C}_{37}$ alkenone concentrations, $\mathrm{U}_{37}^{\mathrm{K}^{\prime}}$ and temperature measurements reported in the studies of Prahl et al. [1989a] and Hoefs et al. [1998] is shown in Table 1 and 2. There is a correlation between temperature differences of the oxidized-unoxidized sediment pairs and alkenone concentrations in the oxidized sections. Temperatures $2.5^{\circ}-3.5^{\circ} \mathrm{C}$ warmer are calculated for the samples with lowest $\mathrm{C}_{37: 3}$ alkenone concentrations (Table 1 and 2). Intermediate values $\left(1.4^{\circ}-1.9^{\circ} \mathrm{C}\right)$ are observed at $\mathrm{C}_{37: 3}$ alkenone concentrations of $0.01-0.02 \mu \mathrm{g} / \mathrm{g}$ (Table 1 and 2), and finally, the smallest temperature deviations $\left(0.4^{\circ}-0.7^{\circ} \mathrm{C}\right)$ correspond to $\left[\mathrm{C}_{37: 3}\right]=0.06-0.2 \mu \mathrm{g} / \mathrm{g}$ (Table 1 and 2). In contrast, the lack of significant temperature differences between unoxidized and oxidized samples described in the study of Prahl et al. [1989a] (Table 1 and 2) is consistent with the considerably higher abundance of $\mathrm{C}_{37: 3}$ alkenone concentrations in the samples analyzed in that study $(0.25 \mu \mathrm{g} / \mathrm{g}$ or more in the oxidized samples).
[25] A representation of the temperature differences versus concentration of total $\mathrm{C}_{37}$ alkenones in the oxidized sediments shows that the samples with highest temperature difference correspond to those of lowest $\mathrm{C}_{37}$ alkenone concentrations (Figure 1). To this end, the oxidized sample studied by Hoefs et al. [1998] that has a similar $\mathrm{C}_{37}$ alkenone concentration to those in the oxidized samples from Prahl et al. [1989a] exhibits a similar temperature difference as those in this latter study (Figure 1). In summary, the discrepant results of the two studies may reflect a case of measurement near the limit of detection in the samples considered by Hoefs et al. [1998].

[26] Gong and Hollander [1999] reported the selective degradation of the $\mathrm{C}_{37: 3}$ alkenone when comparing sediment records in oxic and anoxic sediments from the Santa Monica Basin. In their study, they differentiated between bioturbation and degradation effects in reporting SST estimate offsets of the order of $2.5^{\circ} \mathrm{C}$ due to differential postdepositional transformation of the alkenone mixtures in the sediments. Stronger transformation was observed in the oxic than in the anoxic sediments, corresponding to basin margin and depocenter, respectively. Further investigation of the oceanic regime in this basin is needed for a better appraisal of the represen- 


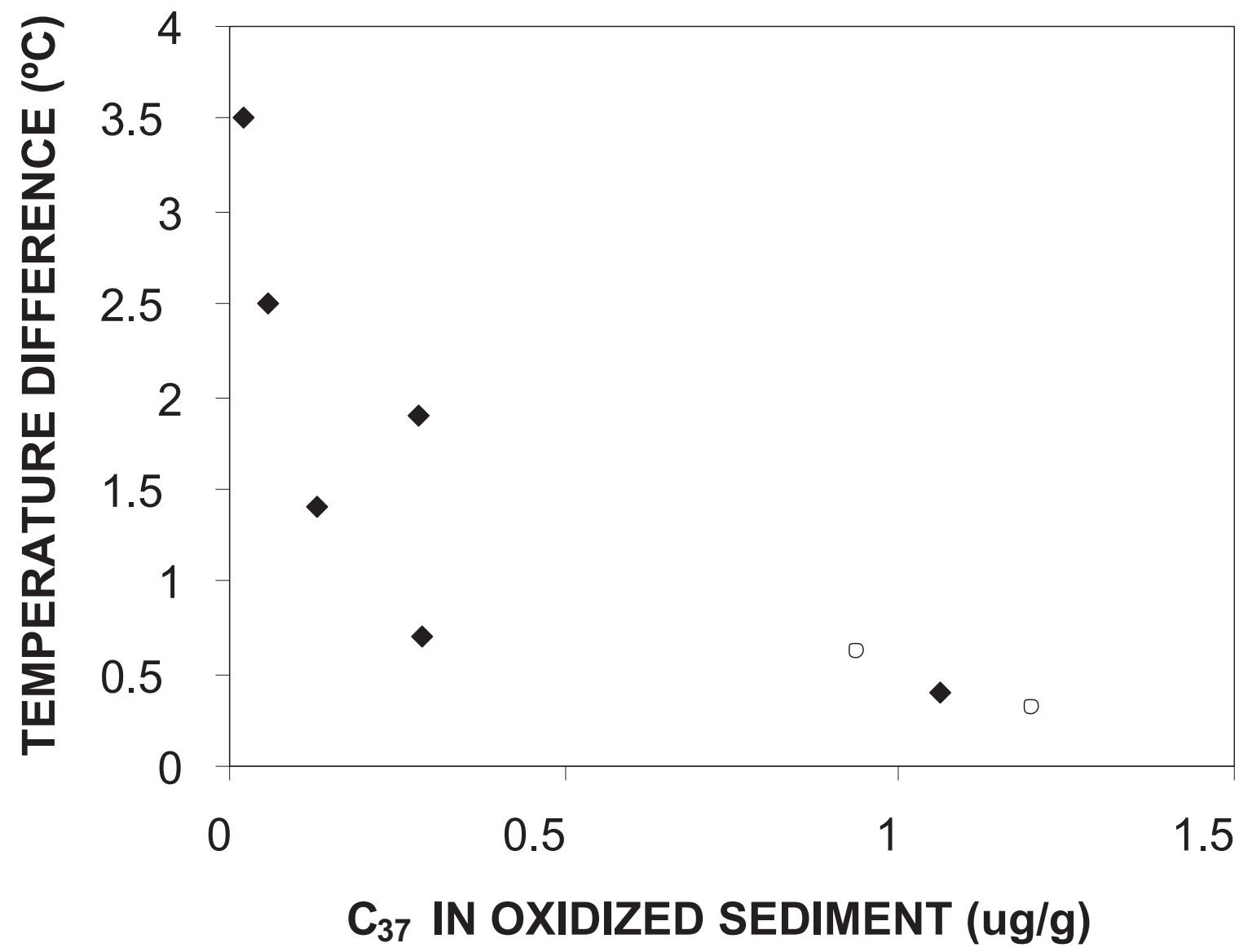

Figure 1. Reported temperature differences between oxidized and nonoxidized sediments in the works of Hoefs et al. [1998] (black diamonds) and Prahl et al. [1989b] (open circles) versus $\mathrm{C}_{37}$ alkenones in the oxidized sediment. Higher temperature differences are observed at lower $\mathrm{C}_{37}$ concentrations.

tativeness of these results in open-marine systems.

\section{Degradation in the Water Column}

[27] It is paramount that we fully understand the processes involved in the transfer of $\mathrm{C}_{37}$ alkenones from the photic zone water column to the underlying sediment in order to correctly interpret the paleoceanographic significance of $\mathrm{U}_{37}^{\mathrm{K}^{\prime}}$ ratios. Issues such as seasonality and water depth of alkenone biosynthesis are very important. Transport mechanisms through the water column and their influence in the preservation/ transformation of the originally synthesized $\mathrm{C}_{37}$ alkenone mixtures are also relevant. This section focuses on the possible degradation processes. Unfortunately, the data available in the literature do not always allow differentiating this single issue within the complexity of the water column-sediment interactions.

\subsection{Difficulties for Comparison Between Water Column and Underlying Sediments}

[28] The comparability of the $\mathrm{C}_{37}$ alkenone composition in the water column and in under- 
lying sediments is difficult owing to the huge timescale differences of the two compartments. Water column particles are collected either by active filtration systems or by passive collection devices, namely, sediment traps. In the first case, sample collection may involve hours or 1 or 2 days at the most. In the second, samples may be collected for 1 or 2 years at weekly or monthly intervals in the most favorable cases. These samples are compared with sediment sections that may represent time-integrated periods of hundreds of years. Furthermore, sediments are not always collected with devices ensuring collection of the true sediment-water interface section. It may happen that core top sediments available for comparison are 1000 or 2000 years old.

[29] These problems are common for all studies involving water column and sediment materials, both organic and inorganic. In the use of $\mathrm{C}_{37}$ alkenones as paleothermometers they become particularly serious owing to the strong requirement for accurate measurements and the need for a correct interpretation of the paleoclimatic signal.

[30] The difficulties in water column-sediment comparison not only involve interannual water column differences but shorter-term changes as well. Seasonality, algal blooms, lateral currents, and many other factors may give rise to major differences in the composition of settling particles during the year. These problems are particularly relevant in suspended particle collection by filtration but also in sediment trap experiments because it has to be shown that the collected particles are representative of the settling flux incorporated into the sediment.

\subsection{Stratified Water Column}

[31] In this context, a direct test of the paleoceanographic significance of the $\mathrm{U}_{37}^{\mathrm{K}^{\prime}}$ index is the comparison between geochemical analysis of filtered particles and in situ temperature measurements. This comparison was performed in the Gulf of Lions, under well-defined water column stratification conditions [Bentaleb et al., 1999]. $\mathrm{U}_{37}^{\mathrm{K}^{\prime}}$ values measured at 5-, 30-, and 1100-m depth corresponded to the level of maximum Hapthophyceae abundance $(30 \mathrm{~m})$. The $\mathrm{U}_{37}^{\mathrm{K}^{\prime}}$ index at $1100 \mathrm{~m}$ was the same as that found at $30 \mathrm{~m}$. These results are in general agreement with sediment trap data from $42^{\circ} \mathrm{N}$ in the eastern Pacific Ocean where it was observed that alkenone production during periods of offshore stratification occurred at the subsurface chlorophyll maximum, and the $\mathrm{U}_{37}^{\mathrm{K}^{\prime}}$ index reflected the temperature measured at this depth [Prahl et al., 1993]. Similar observations were made in depth range studies of alkenone production in the Pacific Ocean based on sediment transects and comparison to Levitus data [Ohkouchi et al., 1999]. At high latitudes $\left(40^{\circ}-48^{\circ} \mathrm{N}\right)$ and in the equatorial region, sedimentary alkenone temperatures correlated well with those in the surface mixing layer, but those at midlatitudes, $\left(19^{\circ}-30^{\circ} \mathrm{N}\right)$ and south of the equator $\left(5^{\circ}-8^{\circ} \mathrm{S}\right)$ correlated with temperatures in thermocline waters below the surface mixing layer. In contrast, in the eastern South Atlantic Ocean $\mathrm{U}_{37}^{\mathrm{K}^{\prime}}$ core top data were always found to correlate with the surface waters' temperature [Müller et al., 1998] probably reflecting low subsurface production due to lack of light penetration to the pycnocline.

\subsection{Total Alkenone Loss}

[32] Measurements of the vertical flux of longchain alkenones and other types of planktonic lipids and comparison of these fluxes with accumulation rates in the underlying sediments showed that the alkenones were considerably more resistant to biodegradation in the settling 
process than most other lipids of planktonic origin [Volkman et al., 1983].

[33] However, in terms of quantitative transfer of these alkenones from the water column to the underlying sediment, contrasting results have been reported. In a comparison between sediment trap (390-m water depth) and underlying sediment composition (4400 m), Prahl and Muehlhausen [1989] observed that the ratio between concentrations of $\mathrm{C}_{37}$ alkenones and total organic carbon (TOC) was $300 \mu \mathrm{g} / \mathrm{g}$ in the sediment traps and $115 \mu \mathrm{g} / \mathrm{g}$ in the underlying sediments $(0.3 \%$ TOC). In a subsequent study, Prahl et al. [1993] reported that the degree of alkenone preservation changed with distance to coast and water column depth. The TOC-normalized alkenone concentrations in the underlying sediments were 81 , 45 , and $8 \%$ of those in the sediment traps (1000-m water depth) for locations situated nearshore (water depth $2712 \mathrm{~m}$ ), further offshore $(3111 \mathrm{~m})$ and central gyre $(3680 \mathrm{~m})$, respectively. In agreement with this trend, no decrease in TOC-normalized alkenone concentrations was observed in the Gulf of California when comparing the compositions of sediment traps (500-m water depth) and underlying sediment (665-m water depth) (D. M. Hartz et al., personal communication, 2000). Conte et al. [1992] also observed a decrease in sedimentary $\mathrm{C}_{37}$ alkenone concentrations in the eastern North Atlantic, paralleling the decrease in TOC.

\subsection{Sediment and Sediment Trap $U_{37}^{K^{\prime}}$ Values}

[34] $\mathrm{U}_{37}^{\mathrm{K}^{\prime}}$ indices in water column-suspended particles and underlying sediments were reported to be in good agreement between these two compartments, e.g., in the Southern Ocean [Sikes et al., 1997]. More data are available on sediment traps that are currently used for studies of $\mathrm{U}_{37}^{\mathrm{K}^{\prime}}$ composition in deep particles. In contrast, data on $\mathrm{C}_{37}$ and $\mathrm{C}_{38}$ alkenoates are scarce.
[35] A very good $\mathrm{U}_{37}^{\mathrm{K}^{\prime}}$ correspondence was observed by Sicre et al. [1999] when comparing sediment traps deployed at 200- and 1000$m$ depth in the northwestern Mediterranean Sea, although the total alkenone flux decreased by $80 \%$ between the shallow and the deep trap. In a previous study in this area, Ternois et al. [1996] found a good correspondence for $\mathrm{U}_{37}^{\mathrm{K}^{\prime}}$ between particles collected with a sediment trap deployed at 200-m depth and the underlying sediment after flux-weighted averaging of the monthly index values. In the eastern North Atlantic, Conte et al. [1992] reported no change in the combined alkenone-alkenoate paleotemperature index between water column (down to $4 \mathrm{~km}$ ) and underlying sediment (down to $4 \mathrm{~cm})$.

[36] A summary of several reported data on $\mathrm{U}_{37}^{\mathrm{K}^{\prime}}$ values in sediment trap material and underlying sediments is given in Table 3. Good agreements were found in the Gulf of California (D. M. Hartz et al., personal communication, 2000), the Norwegian Basin [Thomsen et al., 1998] and the North Pacific off Japan [Sawada et al., 1998]. The Gulf of California studies were performed in the Guaymas Basin. Complete elimination of the alkenones was observed in areas of high hydrothermal activity due to the high temperatures at the seafloor [Simoneit et al., 1994]. In the Norwegian Sea the $\mathrm{U}_{37}^{\mathrm{K}^{\prime}}$ index of the sediment perfectly matched with the alkenone composition of material collected in a trap at 500-m water depth. However, the particles collected at 3000-m water depth exhibited an average index that was 0.6 units higher than in the underlying sediment [Thomsen et al., 1998]. The sediment traps deployed in the North Pacific off Japan extend over the deepest water column ever investigated $(9200 \mathrm{~m})$. No significant change was observed between the average $\mathrm{U}_{37}^{\mathrm{K}^{\prime}}$ of sediment traps deployed at 1674-, 4180-, 5687-, and 8688-m depth (13 samples collected in successive time intervals) 
and the underlying sediment [Sawada et al., 1998].

[37] Some cases where there was no correspondence between particles settling through the water column and underlying sediments are also shown in Table 3. In the Barents Sea, sediment trap data at 1840- and 1950-m water depth and underlying sediment $(2050 \mathrm{~m})$ show considerable scatter. Resuspension and lateral advection have been proposed as explanation of these discrepancies [Thomsen et al., 1998]. A major contrast between annual average sediment trap measurements at $3700 \mathrm{~m}$ and underlying sediment $(4400 \mathrm{~m})$ is reported in the Northeast Atlantic [Rosell-Melé et al., 2000]. Alkenone inputs from elsewhere, e.g., the polar front, instead of overlying waters are proposed as explanation.

[38] A major difference between settling particles $(400 \mathrm{~m})$ and underlying sediment $(2200 \mathrm{~m})$ was observed in the Black Sea [Freeman and Wakeham, 1992]. The discrepancy could be due to the short sampling period over which the sediment trap was deployed (April-July 1988). However, water column alkenone distribution is complex. Water particles (filters) from several depths (10-2000 m) during July 1988 showed an increase with depth in both $\mathrm{U}_{37}^{\mathrm{K}^{\prime}}$ and $\mathrm{U}_{37}^{\mathrm{K}}$. This increase was paralleled by a strong decrease in $\mathrm{C}_{37}$ alkenone concentration (2 orders of magnitude). Lateral transport or phenomena specific to the euxinic environment may also explain this trend (S. G. Wakeham, personal commununication, 1999).

[39] Contrasting results were obtained in the tropical North Pacific Ocean $\left(1^{\circ} \mathrm{N} 138^{\circ} \mathrm{W}\right)$. Prahl and Muehlhausen [1989] found no significant alteration of the qualitative composition of the alkenone mixtures between sediment trap (water depth $3900 \mathrm{~m}, 434$ days deployment) and underlying sediment (4400-m water depth) despite a decrease in the alkenone/TOC ratio by a factor of 3. However, increasing differences in $\mathrm{U}_{37}^{\mathrm{K}^{\prime}}$ index were found by Prahl et al. [1993] in the northeast Pacific Ocean in a transect of three sediment traps and underlying sediments extending from the coast to the open ocean (Table 3): 0.04 (nearshore), 0.05 (further offshore), and 0.12 (gyre).

[40] Overall, these results show a good correspondence between $\mathrm{U}_{37}^{\mathrm{K}^{\prime}}$ indices in water column particles and underlying sediments, indicating that the processes involving quantitative changes in $\mathrm{C}_{37}$ alkenones during particle settling do not result, in general, in significant changes of $\mathrm{U}_{37}^{\mathrm{K}^{\prime}}$. To this end, the results of Sawada et al. [1998] concerning a water column of $9200 \mathrm{~m}$ are particularly significant.

[41] In contrast, there are examples of disagreement between settling water column particles and underlying sediments that cannot be dismissed (e.g., the examples from the Barents and the Black Sea and some case studies in the northeast Pacific Ocean). In the Northeast Pacific study, the authors suggest that the differences observed do not necessarily involve selective degradation of the more unsaturated alkenones. The discrepancies could arise from other mechanisms such as differential preservation of the settling particles arriving at the seafloor over the year because the $\mathrm{U}_{37}^{\mathrm{K}^{\prime}}$ composition of the sediment trap particles collected monthly or weekly is not uniform. In the Barents Sea, Northeast Atlantic and the Black Sea studies the authors propose lateral transport as one of the possible factors explaining the differences. A similar process has been proposed to explain discrepancies between water column temperatures and sedimentary $\mathrm{U}_{37}^{\mathrm{K}^{\prime}}$ measurements in regions of the western South Atlantic such as the Brazil-Falklands Confluence $\left(35^{\circ}-39^{\circ} \mathrm{S}\right)$ and the Falklands Current $\left(41^{\circ}-48^{\circ} \mathrm{S}\right)$ [Benthien and Müller, 2000]. In these regions, strong surface and bottom currents, benthic storms, and downslope processes 
Table 3. Reported Average $U_{37}^{K^{\prime}}$ Data on Sediment Trap Particles and Underlying Sediments

\begin{tabular}{|c|c|c|c|c|}
\hline \multirow[t]{2}{*}{ Location } & \multirow[t]{2}{*}{ Deployment Period } & \multicolumn{2}{|c|}{$\mathrm{U}_{37}^{\mathrm{K}^{\prime}}$ Measurements } & \multirow[t]{2}{*}{ Reference } \\
\hline & & Sediment Traps & Underlying Sediment & \\
\hline $\begin{array}{l}\text { Gulf of California } \\
\quad\left(27^{\circ} 53^{\prime} \mathrm{N}, 111^{\circ} 40^{\prime} \mathrm{W}\right)\end{array}$ & Jan. 14, 1996, to Sept. 21, 1997 & $0.87(500)^{\mathrm{a}}$ & $0.90(665)^{\mathrm{a}}$ & $\begin{array}{l}\text { D. M. Hartz et al. (personal } \\
\text { communication, 2000) }\end{array}$ \\
\hline $\begin{array}{l}\text { Northeast Pacific Ocean } \\
\qquad\left(41^{\circ} 55^{\prime} \mathrm{N}, 125^{\circ} 40^{\prime} \mathrm{W}\right) \\
\left(42^{\circ} 10^{\prime} \mathrm{N}, 127^{\circ} 30^{\prime} \mathrm{W}\right) \\
\left(41^{\circ} 35^{\prime} \mathrm{N}, 131^{\circ} 45^{\prime} \mathrm{W}\right)\end{array}$ & Sept. 22,1987 to Sept. 16, 1988 & $\begin{array}{l}0.38(1000) \\
0.38(1000) \\
0.33(1000)\end{array}$ & $\begin{array}{l}0.42(2712) \\
0.43(3111) \\
0.45(3680)\end{array}$ & Prahl et al. [1993] \\
\hline $\begin{array}{l}\text { Black Sea } \\
\quad\left(43^{\circ} \mathrm{N}, 34^{\circ} \mathrm{E}\right)\end{array}$ & April-July 1988 & $0.15(400)$ & $0.41(2200)$ & Freeman and Wakeham [1992] \\
\hline $\begin{array}{l}\text { Northeast Atlantic } \\
\qquad\left(47^{\circ} 54^{\prime} \mathrm{N}, 21^{\circ} 30^{\prime} \mathrm{E}\right)\end{array}$ & April 1989 to April 1990 & $0.40(3700)$ & $0.57(4400)$ & Rosell-Melé et al. [2000] \\
\hline $\begin{array}{l}\text { Norwegian Basin } \\
\qquad\left(69^{\circ} 41.2^{\prime} \mathrm{N}, 0^{\circ} 27.8^{\prime} \mathrm{E}\right)\end{array}$ & Aug. 1991 to July 1992 & $\begin{array}{l}0.53(500) \\
0.59(3000)\end{array}$ & $0.53(3290)$ & Thomsen et al. [1998] \\
\hline $\begin{array}{l}\text { Barents Sea } \\
\quad\left(75^{\circ} 11.8^{\prime} \mathrm{N}, 12^{\circ} 29.2^{\prime} \mathrm{E}\right)\end{array}$ & March to July 1991 & $\begin{array}{l}0.18(1840) \\
0.76(1950)\end{array}$ & $0.58(2050)$ & Thomsen et al. [1998] \\
\hline $\begin{array}{l}\text { North Pacific off Japan } \\
\quad\left(34^{\circ} 10^{\prime} \mathrm{N}, 142^{\circ} \mathrm{E}\right)\end{array}$ & March 5, 1991 to March 2, 1992 & $\begin{array}{l}0.76(1674) \\
0.74(4180) \\
0.74(5687) \\
0.72(8688)\end{array}$ & $0.74(9200)$ & Sawada et al. [1998] \\
\hline
\end{tabular}

${ }^{a}$ Water column depth is in meters. 
were considered responsible for the colder temperature values recorded in the sediments. Irrespectively of the validity of lateral transport mechanisms in the Barents Sea and the Black Sea, further studies are needed to fully elucidate the factors leading to the water columnsediment discrepancies of SST measurements in these areas.

\subsection{Water Column-Sediment Calibrations}

[42] The discrepant results described above for sediment trap-sediment comparisons cannot be easily attributed to the selective degradation of the more highly unsaturated alkenones. Several examples of inadequate conclusions from the interpretation of discrepant results are available in the literature. In a sediment core top calibration of the $\mathrm{U}_{37}^{\mathrm{K}}$ index versus water column temperatures [Levitus, 1992] in the Atlantic Ocean [Rosell-Melé et al., 1995], selective loss of the more unsaturated alkenones was invoked to explain the steeper slopes in the correlation diagram when compared to other calibrations based on algal cultures or water particles. However, the database on which this intercalibration was based exhibited a considerable amount of scatter at low temperatures. A subsequent study, also based on core tops and involving some of the same authors [Müller et al., 1998], showed a slope identical to the one based on algal cultures [Prahl and Wakeham, 1987]. This was the case when data from the eastern South Atlantic was used or when globally compiling data from the Atlantic, Indian, and Pacific Oceans. In the latter case, since the database was restricted to latitudes between $60^{\circ} \mathrm{N}$ and $60^{\circ} \mathrm{S}$, data points involving high scatter at the low-temperature end were not included. This second study argues for a general correspondence between the $\mathrm{U}_{37}^{\mathrm{K}^{\prime}}$ index and water column temperatures. In this context, the above mentioned examples of discrepancies between sediment trap measurements and underlying sediments seem to be related to specific problems that do not jeopardize the general correspondence between water column temperatures and sedimentary $\mathrm{U}_{37}^{\mathrm{K}^{\prime}}$ index.

\section{6. $\mathrm{C}_{37: 4}$ Alkenone}

[43] Most of the aforementioned data concern the $\mathrm{C}_{37: 2}$ and $\mathrm{C}_{37: 3}$ alkenones. As indicated previously, the $\mathrm{C}_{37: 4}$ alkenone generally occurs in low concentration in many samples and consequently is not considered in the majority of paleotemperature studies. Furthermore, evidence in favor of the simpler $\mathrm{U}_{37}^{\mathrm{K}^{\prime}}$ index providing reliable SST results has led the tetraunsaturated alkenone being disregarded in many studies.

[44] However, the difficulties of including the $\mathrm{C}_{37: 4}$ alkenone in paleotemperature estimation are not only of an analytical nature. Prahl and Muehlhausen [1989] found better correlations between alkenone composition and E. huxleyi growth temperature in the tropical North-Pacific Ocean when the $\mathrm{C}_{37: 4}$ alkenone was not included. They also reported discrepancies between the absence of $\mathrm{C}_{37: 4}$ in the sediments and its presence in the E. huxleyi cultures used for temperature calibration. In agreement with these observations, Sikes et al. [1997] in a calibration between SST and $\mathrm{C}_{37}$ alkenone composition in the Southern Ocean found no correlation between $\mathrm{C}_{37: 4}$ content and SST. Similarly, Freeman and Wakeham [1992], in their analyses of Black Sea water particulates (filters) at several depths from 10 to $2000 \mathrm{~m}$, observed that the concentrations of the $C_{37: 4}$ alkenone did not appear to be related to SST. Furthermore, the $\delta^{13} \mathrm{C}$ composition of the $\mathrm{C}_{37: 4}$ alkenones differed significantly from the isotopic composition of the co-occurring $\mathrm{C}_{37: 2}$ and $\mathrm{C}_{37: 3}$ alkenones (and showed more scatter).

[45] In any case, $\mathrm{C}_{37: 4}$ alkenones are abundant in cold waters, and in these environments they 
can be hardly ignored. Rosell-Melé and Comes [1999] pointed out the difficulties for both $\mathrm{U}_{37}^{\mathrm{K}^{\prime}}$ and $\mathrm{U}_{37}^{\mathrm{K}}$ in providing good estimates of SST during the last glacial maximum in the Nordic seas. Under these conditions a tentative approach based on the $\mathrm{C}_{37: 4}$ content relative to total $\mathrm{C}_{37}$ alkenones allowed the estimation of maximum temperatures of $6^{\circ} \mathrm{C}$ for this period.

[46] Good correlations between $\mathrm{U}_{37}^{\mathrm{K}}$ and SST were found in cold marine environments when the relative abundance of the $\mathrm{C}_{37: 4}$ alkenone was lower than 5\% [Rosell-Melé, 1998]. Conversely, no correlation with SST was found at relative abundances higher than 5\%. Variations in salinity were proposed to explain the $\mathrm{C}_{37: 4}$ distributions in this marine environment at high $\mathrm{C}_{37: 4}$ content [Rosell-Melé, 1998]. The association between low salinities and relative proportion of $\mathrm{C}_{37: 4}$ may be related to changes in the alkenone precursor species. An early work of Cranwell [1985], for example, showed that some freshwater lakes contained unusual alkenone distributions characterized by high proportions of the $\mathrm{C}_{37: 4}$ component. These distributions could not be related to water temperature. Recently, a study on the Baltic Sea also showed the difficulties in relating the $\mathrm{C}_{37}$ alkenone distributions to SST in this basin [Schulz et al., 2000]. Interestingly, the $C_{37}$ alkenone distributions of the inner basins (with less saline waters) of the Baltic Sea exhibited a higher proportion of the $\mathrm{C}_{37: 4}$ alkenone. This enrichment may be due to a stronger influence of freshwater tributaries on these semienclosed areas.

\section{7. $\mathrm{C}_{37}$ and $\mathrm{C}_{38}$ Alkenoates}

[47] Alkenoates have been used for SST estimates in some marine paleoenvironments. They are usually found in higher abundance in the sediments from cold regions, namely, in the North Atlantic. Few data are available on the influence of postdepositional degradation on their composition.
[48] In the studies of Teece et al. [1998], microbial degradation of alkenonates under anoxic conditions was observed, the triunsaturated compound being degraded at a faster rate than the di-unsaturated pseudohomologue. These authors concluded that their results invalidated in practice the alkenoates as sedimentary markers for SST changes.

[49] These results are in agreement with those of a study of Weaver et al. [1999]. In a combined coccolithophorid, foraminiferal, and biomarker reconstruction of paleoceanographic conditions over the past $120 \mathrm{kyr}$ in the northern North Atlantic, these authors observed that the alkenoates were degraded at a faster rate than the alkenones. Accordingly, the former were not suitable for downcore molecular stratigraphy.

\section{Bound Alkenones}

[50] Evidence of storage of alkenones after binding to other compounds is available. The identification of $\mathrm{C}_{37}$ and $\mathrm{C}_{38}$ linear sulfur compounds in ancient samples such as oil shales of Cretaceous origin (e.g., Jurf ed Darawish [Sinninghe Damste et al., 1989]) or sulfur-rich Messinian sediments such as those in the Vena del Gesso Basin (northern Italy) [Koopmans et al., 1997] indicates that the formation of sulfur bound compounds from Hapthophycean lipids is possible. The occurrence of these sulfur-bound compounds is so far restricted to relatively old (e.g., Cretaceous, Miocene) sulfur-rich sedimentary samples, e.g., with an $\mathrm{S}_{\text {org }} / \mathrm{C}$ ratio of 0.08 in the Vena del Gesso samples, which are significantly different from those currently considered in paleoceanographic studies in the Quaternary.

[51] Evidence of lipid sulfur binding in very short timescales is also available. It has been reported for sterols in soil residues [Navarro et al., 1991] and lake sediments [Kok et al., 1999] as well as for tricyclic terpenes in the Cariaco Basin [Koket al., 1999]. No reports are available 
yet for the formation of sulfur-bound alkenones in recent sediments. However, the reports on the early sulfur bonding of other lipid molecules prompt researchers in paleoceanography to check for their possible occurrence in sulfurrich marine sedimentary sequences. A priori sulfur bonding may not alter the $\mathrm{U}_{37}^{\mathrm{K}^{\prime}}$ index [Koopmans et al., 1997], but this aspect has to be confirmed if significant amounts of sulfurbound alkenones being found.

[52] Significant amounts of O-bound alkenones are generated in heating experiments by hydrous pyrolysis (from $160^{\circ}$ to $330^{\circ} \mathrm{C}$ for 72 hours) of the above mentioned Vena del Gesso sediments [Koopmans et al., 1997]. However, these compounds were not initially present in the samples. These experiments mimic the first stages of sedimentary organic matter thermal transformation. However, the organic matter in Pleistocene sediments currently examined in paleoceanographic studies is considerably more immature.

[53] Evidence for the presence of alkenones in the nonsolvent extractable bound fraction released after sediment hydrolysis $(1 \mathrm{~N} \mathrm{KOH})$ has been reported for Pliocene and Miocene sediments [Hoefs et al., 1998]. Again, it remains to be elucidated whether this alkenone fraction may represent a significant proportion of the sedimentary alkenones encountered in Pleistocene sediments. Checking for their occurrence in current paleoceanographic studies, e.g., specific analysis in a representative subseries, may be recommended for inclusion in the good laboratory practices related to the use of alkenones as paleothermometers.

\section{Use of $\mathrm{C}_{37}$ Alkenones as Paleoproductivity Proxy}

\subsection{Productivity Records}

[54] Sedimentary $\mathrm{C}_{37}$ alkenones have been proposed as indicators of paleoproductivity in addition to TOC, which is also used for this purpose, e.g., in the Atlantic [Sikes and Keigwin, 1994, 1996; Rosell-Melé and Koç, 1997; Villanueva et al., 1997, 1998; Weaver et al., 1999; Sicre et al., 2000; Ternois et al., 2000; Werne et al., 2000], Pacific [Farrington et al., 1988; Kennedy and Brassell, 1992; Prahl et al., 1989a; Herbert et al., 1998; Ohkouchi et al., 1999], and Indian Oceans [Sonzogni et al., 1998] as well as in the Arabian Sea [Schubert et al., 1998; Budziak et al., 2000]. As with TOC and many other lipids and pigments, their usefulness as paleoproductivity markers is dependent on the uniformity of the preservation conditions in the period of study.

[55] $\mathrm{C}_{37}$ alkenones reflect the productivity signal related to Hapthophyceae because these compounds are specific markers of some species within this algal class. Thus positive correlations between $\mathrm{C}_{37}$ alkenone concentrations and coccolith abundances have been reported [Weaver et al., 1999].

[56] However, the environmental conditions giving rise to enhanced productivity by Hapthophyceae, e.g., nutrient availability, are also adequate for the growth of many other algae. Thus the record of productivity signals integrated over long time periods show good parallelisms between abundances of $\mathrm{C}_{37}$ alkenones and other proxies for global productivity such as total chlorin concentrations [Schubert et al., 1998] or foraminifera accumulation rates [Sikes and Keigwin, 1994, 1996]. These apparently good correlations are also observed when comparing with specific biomarkers of algae other than Haptophyceae such as dinosterol and $4 \alpha-$ methylstanols [Prahl et al., 1989a; Schubert et al., 1998] and brassicasterol [Schubert et al., 1998].

[57] Therefore $\mathrm{C}_{37}$ alkenones follow the global productivity record in many marine environments because increase of productivity 
involves covariant changes in the abundance of many algal species. However, this is not always the case. Diatoms are the species of larger phytoplankton blooms in upwelling areas and are more representative of highproductivity conditions. In some of these systems, Hapthophyceae may become relevant at lower productivity and not be correlated with the diatom markers. An example of the changes of $\mathrm{C}_{37}$ alkenones and diatom sterols in a specific environment is that of the Cariaco Basin [Werne et al., 2000]. In this case, low-productivity periods exhibited high $\mathrm{C}_{37}$ alkenone concentrations and highproductivity episodes recorded high concentrations of brassicasterol, fucosterol, $\beta$-sitosterol, $\Delta^{22}$-cholesterol, and other diatom sterols. However, in more open upwelling systems, e.g., the northwestern African continental margin, paleoproductivity is recorded by $\mathrm{C}_{37}$ alkenones as evidenced by the good parallelism between markers of wind intensity ( $n$-alkanols) and these algal compounds [Ternois et al., 2000].

[58] The use of $\mathrm{C}_{37}$ alkenone concentrations/ fluxes has successfully allowed the identification of a precessional forcing of algal productivity in the North Atlantic Ocean [Villanueva et al., 1998] and in the Arabian Sea [Budziak et al., 2000]. Except for the above mentioned upwelling areas, the changes in $\mathrm{C}_{37}$ alkenone fluxes in the sediment records could be interpreted as diagnostic for marine productivity because these fluxes encompass long deposition periods. The high resistance of alkenones to degradation compared to other lipids points to the alkenones as reasonable biomarkers for this purpose.

\subsection{Marine Versus Terrigenous TOC}

[59] A direct proportion between marine TOC and $\mathrm{C}_{37}$ alkenones was observed in a $105-\mathrm{kyr}$ Deep Sea Drilling Project core from the Pigmy Basin (Gulf of Mexico), which is under the influence of the Mississippi River discharges [Jasper and Gagosian, 1993]. Comparison of $\mathrm{C}_{37}$ alkenone/TOC and $\delta^{13} \mathrm{C}_{\text {org }}$ values measured on total organic carbon showed a linear correlation between the two parameters $(r=$ $0.85)$. The obvious interpretation of this correlation is a constant $C_{37}$ alkenone/ $C_{\text {marine org }}$ ratio and a correspondence between $\delta^{13} \mathrm{C}_{\text {org }}$ and relative content of terrigenous/marine organic matter supply.

[60] Positive correlations between $\mathrm{C}_{37}$ alkenone concentrations and TOC were also observed in the Arabian Sea [Schubert et al., 1998], the Indian Ocean [Rostek et al., 1994], the African continental margin [Ternois et al., 2000] and the equatorial Atlantic [Sikes and Keigwin, 1994]. A constant $C_{37}$ alkenone/TOC ratio was also assumed in the mass balances of terrigenous and marine organic matter in the North Atlantic that allowed a successful description of sedimentary TOC origin during the last interglacial period [Villanueva et al., 1997].

\section{Stability of the $\delta^{13} \mathrm{C}$ Composition of Alkenones}

[61] Although the biochemical fate of alkenones may vary among different compartments of the algal cell, no changes in $\delta^{13} \mathrm{C}$ composition should be expected in residual $\mathrm{C}_{37}$ alkenone after degradation. Accordingly, no significant changes were observed by Grice et al. [1998] in experiments involving the ingestion of Isochrysis galbana by the copepod Temora longicornis. However, the paucity of literature evidence on the stability of the $\delta^{13} \mathrm{C}$ isotopic signal in the alkenones should stimulate caution and further investigation.

\section{Conclusions}

[62] There is no consistent evidence of selective biogenic degradation of the $\mathrm{C}_{37: 2}$ and $\mathrm{C}_{37: 3}$ 
alkenones by biota. Studies in the literature reporting no or minor changes of $\mathrm{U}_{37}^{\mathrm{K}^{\prime}}$ as a consequence of $\mathrm{C}_{37}$ alkenone degradation in sediments or in the water column outweigh those in which significant changes were observed. However, the amount of data on this topic is clearly insufficient. Many more experiments encompassing the whole range of $\mathrm{U}_{37}^{\mathrm{K}^{\prime}}$ values, different water column environments, and sedimentary conditions are needed.

[63] Reports indicating lacking, weak, or no dependence of the $C_{37: 4}$ alkenone on growth temperature suggest that in most cases the $\mathrm{U}_{37}^{\mathrm{K}^{\prime}}$ ratio will be a better proxy for paleotemperature estimate than $\mathrm{U}_{37}^{\mathrm{K}}$. This conclusion is consistent with most of the work in the literature involving the use of $\mathrm{C}_{37}$ alkenones for paleo-SST estimation. However, in high latitudes, e.g., the Nordic Seas, the $\mathrm{C}_{37: 4}$ alkenone is needed for a global understanding of the dependence between $\mathrm{C}_{37}$ alkenone distributions and SST.

[64] The $\mathrm{C}_{37}$ and $\mathrm{C}_{38}$ alkenoates exhibit major changes in relative proportion upon degradation under anoxic conditions. These compounds may only be useful for paleotemperature estimation in very specific environments.

[65] $\mathrm{C}_{37}$ alkenones can be used, as many other proxies (including organic carbon), to get qualitative estimates of paleoproductivity changes over "long" sedimentation periods (circa kiloyears). This application depends on the uniformity of the degradation conditions, as is the case for TOC and other lipids and pigments.

\section{Recommendations}

[66] 1. Studies of SST using the $\mathrm{U}_{37}^{\mathrm{K}^{\prime}}$ index should always include concentration data of all alkenones, both those used in SST calculation and others that may be observed but not used. The $\mathrm{C}_{37: 4}$ alkenone should be included where observed. In the case of small data sets, numerical values should be tabulated in the article. For larger data sets, electronic access by the scientific community should be arranged by either inclusion in currently established databases or via linkages to related sites. Consideration should be given to a global database of alkenone distributions in water columns and sediments.

[67] 2. Information on the intermediate products and likely reaction pathways of degradation during alkenone diagenesis is needed. This will help to evaluate whether the first site of attack is at the keto group (no effect on $\mathrm{U}_{37}^{\mathrm{K}^{\prime}}$ expected) or at the double bonds, which may affect the alkenone index over long timescales in sediments.

[68] 3. Information on the effects of bioturbation on selective preservation of alkenones in surface sediments is lacking. Although experimental studies in water columns indicate that microbial and mesozooplankton grazers do not alter the index, this should be validated for benthic consumers.

[69] 4. Further assessment is needed on the possible transformation of the $\mathrm{U}_{37}^{\mathrm{K}^{\prime}}$ ratio upon sedimentation under oxic-anoxic sedimentary conditions. Despite the overwhelming evidence for the postdepositional stability of this index, the data from the Santa Monica Basin [Gong and Hollander, 1999] suggest that assessment on the postdepositional changes of the relative composition of $\mathrm{C}_{37: 2}$ and $\mathrm{C}_{37: 3}$ alkenones should be continued. A larger number of cores in this basin should be studied for a better understanding of the changes observed. Other basins encompassing oxic-anoxic sedimentary conditions should also be considered.

[70] 5. Other sedimentary lipids, namely, those more labile than the alkenones, can be used as indicators of possible alkenone degradation in 
the sedimentary system under study. Quantitative analysis of these lipids and evaluation of their downcore degradation trends may provide a useful comparison for the stability of the $\mathrm{U}_{37}^{\mathrm{K}^{\prime}}$ index.

[71] 6. The processes of alkenone binding, including sulfurization or direct coupling, to macromolecular organic matter are not known. Studies that consider the mechanisms of lipid binding over long timescales would be useful. In practice, $\mathrm{C}_{37}$ alkenone users should evaluate whether these processes are relevant for their samples under study. Analysis of subseries of sediments for this purpose may be included as a good laboratory practice in the use of alkenones as paleothermometers.

[72] 7. Knowledge is needed on the distribution of alkenones among different size fractions of particles in the water column and surface sediments. This would allow the reconstruction of alkenone transport pathways in water columns and provide insight into their potential redistribution at the sedimentwater interface.

[73] 8. Organic carbon and pigment content should be included among the parameters measured wherever possible. This is of particular interest given the links between alkenone contents in sediments and issues of paleoproductivity and preservation.

[74] 9. The integrity of the isotopic signal during diagenesis should be validated.

\section{References}

Bentaleb, I., J. O. Grimalt, F. Vidussi, J.-C. Marty, V. Martin, M. Denis, C. Hatté, and M. Fontugne, The $\mathrm{C}_{37}$ alkenone record of seawater temperature during seasonal thermocline stratification, Mar. Chem., 64, 301313, 1999.

Benthien, A., and P. J. Müller, Anomalously low alkenone temperatures caused by lateral particle and sediment transport in the Malvinas Current region, western Argentine Basin, Deep Sea Res. I, in press, 2000.

Brassell, S. C., Applications of biomarkers for delineating marine paleoclimatic fluctuations during the Pleistocene, in Organic Geochemistry, edited by M. H. Engel and S. A. Macko, pp. 699-738,Plenum, New York, 1983.

Brassell, S. C., G. Eglinton, I. T. Marlowe, U. Pflaumann, and M. Sarnthein, Molecular stratigraphy: A new tool for climatic assessment, Nature, 320, 129-133, 1986a.

Brassell, S. C., R. G. Brereton, G. Eglinton, J. O. Grimalt, G. Liebezeit, I. T. Marlowe, U. Pflaumann, and M. Sarnthein, Palaeoclimatic signals recognized by chemometric treatment of molecular stratigraphic data, Org. Geochem., 10, 649-660, 1986b.

Budziak, D., R. R. Schneider, F. Rostek, P. J. Müller, E. Bard, and G. Wefer, Late Quaternary insolation forcing on total organic carbon and $\mathrm{C}_{37}$ alkenone variations in the Arabian Sea, Paleoceanography, 15, 307-321, 2000.

Conte, H. M., G. Eglinton, and L. A. S. Madureira, Longchain alkenones and alkyl alkenoates as palaeotemperature indicators: Their production, flux and early sedimentary diagenesis in the Eastern North Atlantic, Org. Geochem., 19, 287-298, 1992.

Cranwell, P. A., Long-chain unsaturated ketones in recent lacustrine sediments, Org. Geochem., 49, 1545-1551, 1985.

Farrington, J. W., A. C. Davis, J. Sulanowski, M. A. McCaffrey, M. McCarthy, C. H. Clifford, P. Dickinson, and J. K. Volkman, Biogeochemistry of lipids in surface sediments of the Peru Upwelling Area $15^{\circ} \mathrm{S}$, Org. Geochem., 13, 607-617, 1988.

Freeman, K. H., and S. G. Wakeham, Variations in the distributions and isotopic compositions of alkenones in Black Sea particles and sediments, Org. Geochem., 19, 277-285, 1992.

Gong, C., and D. J. Hollander, Differential contribution of bacteria to sedimentary organic matter in oxic and anoxic environments, Santa Monica Basin, California, Org. Geochem., 26, 545-563, 1997.

Gong, C., and D. J. Hollander, Evidence for the differential degradation of alkenones under contrasting bottom water oxygen conditions: Implication for paleotemperature reconstruction, Geochim. Cosmochim. Acta, 63, 405-411, 1999.

Grice, K., W. C. M. K. Breteler, S. Schouten, and V. Grossi, Effects of zooplankton herbivory on biomarker proxy records, Paleoceanography, 13, 686-693, 1998.

Herbert, T. D., J. D. Schuffert, D. Thomas, C. Lange, A. Weinheimer, A. Peleo-Alampay, and J.-C. Herguera, Depth and seasonality of alkenone production along 
the California margin inferred from a core top transect, Paleoceanography, 13, 263-271, 1998.

Hoefs, M. J. L., G. J. M. Versteegh, W. I. C. Rijpstra, J. W. de Leeuw, and J. S. Sinninghe Damste, Postdepositional oxic degradation of alkenones: Implications for the measurement of paleo sea surface temperatures, $\mathrm{Pa}$ leoceanography, 13, 42-49, 1998.

Jasper, J., and R. B. Gagosian, The relationship between sedimentary organic carbon isotopic composition and organic biomarker compound concentration, Geochim. Cosmochim. Acta, 57, 167-186, 1993.

Kennedy, J. A., and S. C. Brassell, Molecular records of twentieth-century El Niño events in laminated sediments from the Santa Barbara Basin, Nature, 357, 62-64, 1992.

Kok, M. D., J. P. Werne, W. I. C. Rijpstra, L. Robertson, J. K. Volkman, D. J. Hollander, and J. S. Sinninghe Damsté, Direct proof of early sulfurization of organic matter in surface sediments, in 19th International Meeting on Organic Geochemistry, vol 1. pp. 155-156,Marmara Res. Cent., Tubitak, Turkey, 1999.

Koopmans, M. P., C. Schaeffer-Reiss, J. W. de Leeuw, M. D. Lewan, J. R. Maxwell, P. Schaeffer, and J. S. Sinninghe Damsté, Sulphur and oxygen sequestration of $n$ $\mathrm{C}_{37}$ and $n-\mathrm{C}_{38}$ unsaturated ketones in an immature kerogen and the release of their carbon skeletons during early stages of thermal maturation, Geochim. Cosmochim. Acta, 61, 2397-2408, 1997.

Levitus, S., Climatological Atlas of the World Oceans, U.S. Govt. Printing Office, Washington, D. C., 1992.

Madureira, L. A. S., M. H. Conte, and G. Eglinton, Early diagenesis of lipid biomarker compounds in North Atlantic sediments, Paleoceanography, 10, 627-642, 1995.

McCaffrey, M. A., J. W. Farrington, and D. J. Repeta, The organic geochemistry of Peru margin surface sediments, I, A comparison of the $\mathrm{C}_{37}$ alkenone and historical El Niño records, Geochim. Cosmochim. Acta, 54, 16711682, 1990.

Müller, P. J., G. Kirst, G. Ruhland, I. Von Storch, and A. Rosell-Melé, Calibration of the alkenone paleotemperature index $\mathrm{U}_{37}^{\mathrm{K}^{\prime}}$ based on core-tops from the eastern South Atlantic and the global ocean $\left(60^{\circ} \mathrm{N}-60^{\circ} \mathrm{S}\right)$, Geochim. Cosmochim. Acta, 62, 1757-1772, 1998.

Navarro, A., A. Rosell, J. Villanueva, and J. O. Grimalt, Monitoring of hazardous waste dumps by the study of metals and solvent- soluble organic chemicals, Chemosphere, 22, 913-928, 1991.

Ohkouchi, N., K. Kawamura, H. Kawahata, and H. Okada, Depth ranges of alkenone production in the central Pacific Ocean, Global Biogeochem. Cycles, 13, 695704, 1999.

Pelejero, C., and J. O. Grimalt, The correlation between the $\mathrm{U}_{37}^{\mathrm{K}}$ index and sea surface temperatures in the warm boundary: The South China Sea, Geochim. Cosmochim. Acta, 61, 4789-4797, 1997.

Prahl, F. G., and L. A. Muehlhausen, Lipid biomarkers as geochemical tools for paleoceanograpic study, in Productivity of the Ocean: Present and Past, edited by W. H. Berger, V. S. Smetacek, and G. Wefer, pp. $271-$ 289,John Wiley, New York, 1989.

Prahl, F. G., and S. G. Wakeham, Calibration of unsaturation patterns in long-chain ketone compositions for paleotemperature assessment, Nature, 330, 367-369, 1987.

Prahl, F. G., L. A. Muehlhausen, and D. L. Zahnle, Further evaluation of long-chain alkenones as indicators of paleoceanographic conditions, Geochim. Cosmochim. Acta, 52, 2303-2310, 1988.

Prahl, F. G., L. A. Muehlhausen, and M. Lyle, An organic geochemical assessment of oceanographic conditions at Manop site $\mathrm{C}$ over the past 26,000 years, Paleoceanography, 4, 495-510, 1989a.

Prahl, F. G., G. J. de Lange, M. Lyle, and M. A. Sparrow, Post-depositional stability of long-chain alkenones under contrasting redox conditions, Nature, 341, 434-437, 1989b.

Prahl, F. G., R. B. Collier, J. Dymond, M. Lyle, and M. A. Sparrow, A biomarker perspective on prymnesiophyte productivity in the northeastern Pacific Ocean, Deep Sea Res. I, 40, 2061-2076, 1993.

Rechka, J. A., and J. Maxwell, Unusual long chain ketones of algal origin, Tetrahedron Lett., 29, 2599-2600, 1988.

Rosell-Melé, A., Interhemispheric appraisal of the value of alkenone indices as temperature and salinity proxies in high-latitude locations, Paleoceanography, 13, 694703, 1998.

Rosell-Melé, A., and P. Comes, Evidence for a warm Last Glacial Maximum in the North seas or an example of shortcomings in $\mathrm{U}_{37}^{\mathrm{K}^{\prime}}$ and $\mathrm{U}_{37}^{\mathrm{K}}$ to estimate low sea surface temperature?, Paleoceanography, 14, 770776, 1999.

Rosell-Melé, A., and N. Koç, Paleoclimatic significance of the stratigraphic occurrence of photosynthetic biomarker pigments in the Nordic seas, Geology, 25, 4952, 1997.

Rosell-Melé, A., G. Eglinton, U. Pflaumann, and M. Sarnthein, Atlantic core-top calibration of the $\mathrm{U}_{37}^{\mathrm{K}}$ index as a sea-surface palaeotemperature indicator, Geochim. Cosmochim. Acta, 59, 3099-3107, 1995.

Rosell-Melé, A., P. Comes, P. J. Müller, and P. Ziveri, Alkenone fluxes and anomalous $\mathrm{U}_{37}^{\mathrm{K}^{\prime}}$ values during $1989-1990$ in the Northeast Atlantic $\left(48^{\circ} \mathrm{N} 21^{\circ} \mathrm{W}\right)$, Mar. Chem., 71, 251-264, 2000.

Rostek, F., G. Ruhland, F. C. Bassinot, L. Beaufort, P. J. 
Müller, and E. Bard, Fluctuations of the Indian monsoon regime during the last 170,000 years: Evidence from sea surface temperature, salinity and organic carbon records, in Global Precipitations and Climatic Change, edited by M. Desbois and F. Désalmand, vol. I26, pp. 2751,Springer-Verlag, New York, 1994.

Sawada, K., N. Handa, and T. Nakatsuda, Production and transport of long-chain alkenones and alkyl alkenoates in a sea water column in the northwestern Pacific off central Japan, Mar. Chem., 59, 219-234, 1998.

Schubert, C. J., J. Villanueva, S. E. Calvert, G. L. Cowie, U. von Rad, H. Schulz, U. Berner, and H. Erlenkeuser, Stable phytoplankton community structure in the Arabian Sea over the past 200,000 years, Nature, 394, $563-$ 566, 1998.

Schulz, H.-M., A. Schöner, and K.-C. Emeis, Long-chain alkenone patterns in the Baltic Sea-An ocean-freshwater transition, Geochim. Cosmochim. Acta, 64, 469-477, 2000.

Sicre, M.-A., Y. Ternois, J.-C. Miquel, and J.-C. Marty, Alkenones in the Northwestern Mediterranean Sea: Interannual variability and vertical transfer, Geophys. Res. Lett., 26, 1735-1738, 1999.

Sicre, M.-A., Y. Ternois, M. Paterne, A. Boireau, L. Beaufort, P. Martinez, and P. Bertrand, Biomarker stratigraphy records over the last 150 kyears off the NW African coast at $25^{\circ} \mathrm{N}$, Org. Geochem., 31, 577-588, 2000.

Sikes, E. L., and L. D. Keigwin, Equatorial Atlantic sea surface temperature for the last $30 \mathrm{kyr}$ : A comparison of $\mathrm{U}_{37}^{\mathrm{K}^{\prime}}, \delta^{18} \mathrm{O}$ and foraminiferal assemblage temperature estimates, Paleoceanogr., 9, 31-45, 1994.

Sikes, E. L., and L. D. Keigwin, A reexamination of northeast Atlantic sea surface temperature and salinity over the last $16 \mathrm{kyr}$, Paleoceanography, 11, 327-342, 1996.

Sikes, E. L., and J. K. Volkman, Calibration of alkenone unsaturation ratios $\left(\mathrm{U}_{37}^{\mathrm{K}}\right)$ for paleotemperature estimation in cold polar waters, Geochim. Cosmochim. Acta, 57, 1883-1889, 1993.

Sikes, E. L., J. W. Farrington, and L. D. Keigwin, Use of the alkenone unsaturation ratio $\mathrm{U}_{37}^{\mathrm{K}}$ to determine past sea surface temperatures: Core-top SST calibrations and methodology considerations, Earth Planet. Sci. Lett., 104, 36-47, 1991.

Sikes, E. L., J. K. Volkman, L. G. Robertson, and J.-J. Pichon, Alkenones and alkenes in surface waters and sediments of the Southern Ocean: Implications for paleotemperature estimation in polar regions, Geochim. Cosmochim. Acta, 61, 1495-1505, 1997.

Simoneit, B. R. T., F. G. Prahl, R. N. Leif, and S.-Z. Zhao, Alkenones in sediments of Middle Valley, Leg 139: Application as thermal sensors, in Proceedings of the Ocean Drilling Program, Scientific Results, edited by
M. J. Mottl et al., vol. 40, pp. 479-484,Ocean Drill. Program, College Station, Tex., 1994.

Sinninghe Damste, J. S., W. I. C. Rijpstra, A. C. Kockvan-Dalen, J. W. de Leeuw, and P. A. Schenck, Quenching of labile functionalised lipids by inorganic sulphur species: Evidence for the formation of sedimentary organic sulphur compounds at the early stages of diagenesis, Geochim. Cosmochim. Acta, 53, 1343-1355, 1989.

Sonzogni, C., E. Bard, F. Rostek, R. Lafont, A. RosellMelé, and G. Eglinton, Core-top calibration of the alkenone index vs. sea surface temperature in the Indian Ocean, Deep Sea Res. II, 44, 1445-1460, 1997.

Sonzogni, C., E. Bard, and F. Rostek, Tropical sea-surface temperatures during the last glacial period: A view based on alkenones in Indian Ocean sediments, Quat. Sci. Rev., 17, 1185-1201, 1998.

Sun, M.-Y., and S. G. Wakeham, Molecular evidence for degradation and preservation of organic matter in the anoxic Black Sea Basin, Geochim. Cosmochim. Acta, 58, 3395-3406, 1994.

Teece, M. A., J. M. Getliff, J. W. Leftley, R. J. Parkes, and J. R. Maxwell, Microbial processes involved in the degradation and survival of algal lipid biomarkers, in $\mathrm{Or}$ ganic Geochemistry: Developments and Applications to Energy, Climate, Environment and Human History, edited by J. O. Grimalt and C. Dorronsoro, pp. 898901,AIGOA, Donostia-San Sebastian, Spain, 1995.

Teece, M. A., J. M. Getliff, J. W. Leftley, R. J. Parkes, and J. R. Maxwell, Microbial degradation of the marine prymnesiophyte Emiliania huxleyi under oxic and anoxic conditions as a model for early diagenesis: Long chain alkadienes, alkenones and alkyl alkenoates, Org. Geochem., 29, 863-880, 1998.

Ternois, Y., M.-A. Sicre, A. Boireau, J.-C. Marty, and J.C. Miquel, Production pattern of alkenones in the Mediterranean Sea, Geophys. Res. Lett., 23, 3171-3174, 1996.

Ternois, Y., M.-A. Sicre, A. Boireau, M. H. Conte, and G. Eglinton, Evaluation of long-chain alkenones as paleotemperature indicators in the Mediterranean Sea, Deep Sea Res. I, 44, 271-286, 1997.

Ternois, Y., M.-A. Sicre, and M. Paterne, Climatic changes along the northwestern African continental margin over the last $30 \mathrm{kyrs}$, Geophys. Res. Lett., 27 , $133-136,2000$.

Thomsen, C., D. E. Schulz-Bull, G. Petrick, and J. C. Duinker, Seasonal variability of the long-chain alkenone flux and the effect on the $\mathrm{U}_{37}^{\mathrm{K}^{\prime}}$-index in the Norwegian Sea, Org. Geochem., 28, 311-323, 1998.

Villanueva, J., and J. O. Grimalt, Gas chromatographic tuning of the $\mathrm{U}_{37}^{\mathrm{K}^{\prime}}$ paleothermometer, Anal. Chem., 69, 3329-3332, 1997. 
Villanueva, J., J. O. Grimalt, E. Cortijo, L. Vidal, and L. Labeyrie, A biomarker approach to the organic matter deposited in the North Atlantic during the last climatic cycle, Geochim. Cosmochim. Acta, 61,4633-4646, 1997.

Villanueva, J., J. O. Grimalt, L. D. Labeyrie, E. Cortijo, L. Vidal, and J.-L. Turon, Precessional forcing of productivity in the North Atlantic Ocean, Paleoceanography, $13,561-571,1998$

Volkman, J. K., G. Eglinton, E. D. S. Corner, and J. R. Sargent, Novel unsaturated straight-chain methyl and ethyl ketones in marine sediments and a coccolithophore Emiliania huxleyi, in Advances in Organic Geochemistry 1979, edited by A. G. Douglas and J. R. Maxwell, pp. 219-227,Pergamon, New York, 1980.

Volkman, J. K., J. W. Farrington, R. B. Gagosian, and S.
G. Wakeham, Lipid composition of coastal marine sediments from the Peru upwelling region, in Advances in Organic Geochemistry 1981, edited by M. Bjoroy et al., pp. 228-240,John Wiley, New York, 1983.

Weaver, P. P. E., M. R. Chapman, G. Eglinton, M. Zhao, D. Rutledge, and G. Read, Combined coccolith, foraminiferal, and biomarker reconstruction of paleoceanographic conditions over the past $120 \mathrm{kyr}$ in the northern North Atlantic $\left(59^{\circ} \mathrm{N}, 23^{\circ} \mathrm{W}\right)$, Paleoceanography, 14, 336-349, 1999.

Werne, J. P., D. J. Hollander, T. W. Lyons, and L. C. Peterson, Climate-induced variations in productivity and planktonic ecosystem structure from the Younger Dryas to Holocene in the Cariaco Basin, Venezuela, Paleoceanography, 15, 19-29, 2000. 